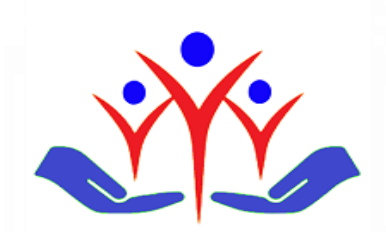

ISSN $2458-8865$

Case Report

\title{
Herpes zoster infection in early adolescence: two case reports and review of the treatment approach
}

Erken adölesan dönemde Herpes Zoster enfeksiyonu: İki olgu sunumu ve tedavi yaklaşımının gözden geçirilmesi

\author{
D Ramazan Cahit Temizkan ${ }^{\mathrm{a}}$, Nurcan Unal $^{\mathrm{a}}$, Muhammet Mesut Nezir Engin $^{\mathrm{a}}$, Onder Kilicaslan ${ }^{\mathrm{a}}$, \\ Kenan Kocabay ${ }^{\mathrm{a}}$ \\ $\mathbf{a}$ Department of Pediatrics, Duzce University, Duzce, Turkey
}

\begin{abstract}
Introduction: Herpes zoster is a skin infection caused by reactivation of the Varicella zoster virus that remains latent in the dorsal root ganglia, showing dermatomal spread on the skin, accompanied by a vesicular rash and itching. It is a disease of the adult age group. Although herpes zoster is more common in immunocompromised children, it is rarely seen in healthy children.

Case Presentation: Two patients, 11 and 12 years old, presented with pain, itching, and rash. Patient histories indicated that they were previously healthy. Alanine aminotransferase, aspartate aminotransferase, urea, blood urea nitrogen, creatinine, and electrolyte values were within normal limits. Varicella-zoster virus (VZV) immunoglobulin (Ig) G and VZV Ig M were positive, while herpes zoster virus (HZV) Ig G and HZV Ig M were negative. Oral acyclovir treatment was started. Symptoms, treatment, and follow-up of the two cases were similar. In both patients, the lesions regressed within a week, and at the end of the second week, they recovered without complications.

Conclusion: Herpes Zoster infection is rarely seen in healthy children. In this case report, we aimed to remind and discuss the clinical features during childhood.
\end{abstract}

Keywords: Adolescent, Herpes Zoster, Rash

\section{ÖZ}

Giriş: Herpes zoster (HZ), dorsal kök gangliyonlarında latent kalarak Varisella zoster virüsün reaktivasyonu sonucunda oluşan, deride dermatomal yayılım gösteren, veziküler döküntü ile seyreden çoğunlukla ağrı ve kaşıntının eşlik ettiği cilt enfeksiyonudur. Erişkin yaş grubunun hastalığıdır. Hastalık genellikle immünsupresif çocuklarda daha sık görülmekle birlikte, sağlıklı çocuklarda nadir olarak görülmektedir.

Vaka Sunumu: Tarafımıza 11 ve 12 yaşında iki hasta ağrı, kaşıntı ve döküntü şikâyetiyle başvurdular Alınan anamnezde önceden sağlıklı oldukları ögrenilen hastaların bakılan alanin aminotrasferaz, aspartat amino transferaz, üre, BUN, kreatinin ve elektrolit değerleri normal sınırlardaydı. Varicella zoster virüs (VZV) immunglobulin (Ig) G ve VZV IgM pozitif, herpes zoster virüs (HZV) IgG ve HZV IgM negatif olarak sonuçlandı. Hastalara oral asiklovir tedavisi başlandı. Olgulardaki semptomlar, tedavi ve takip süreci benzerdi. Her iki olgunun da lezyonları bir hafta içerisinde gerilemiş olup, ikinci haftanın sonunda lezyonlar komplikasyonsuz olarak iyileşti.

Sonuç: Herpes Zoster enfeksiyonu sağlıklı çocuklarda nadir görülür ve bu olgu sunumuyla çocukluk çağının klinik özelliklerinin hatırlatılması ve tartışılması amaçlandi.

Anahtar Kelimeler: Adölesan, Herpes Zoster, Döküntü

\begin{tabular}{|c|c|c|c|c|}
\hline Received & Accepted & Published Online & Corresponding Author & E-mail \\
\hline January 17, 2019 & October 31, 2019 & September 30, 2020 & Muhammet Mesut Nezir Engin, MD & doktormesut@ @hotmail.com \\
\hline Correspondence & $\begin{array}{l}\text { Dr. Muhammet Mesut Nezir Engin, Düzce Üniversitesi, Tıp Fakültesi, Çocuk Sağlı̆̆ ve Hastalıkları } \\
\text { Anabilim Dalı, Duzce, Turkey. }\end{array}$ \\
\hline
\end{tabular}




\section{Introduction}

Herpes zoster (HZ) is a skin infection that occurs as a result of reactivation of the Varicella zoster virus (VZV), which remains latent in the dorsal root ganglia, which shows dermatomal spread on the skin, accompanied by a vesicular rash, often together with pain and itching [1-2]. The disease is more common in the adult age group, and it is sporadic among children [1-4]. Herpes zoster incidence rate is $2.5 / 1000$ in adults aged 20-40 and $10 / 1000$ at an age above 70 [1]. The incidence in children varies between 2-7.4/10,000 per year. [4]. The disease is more common in immunosuppressive children, and it is rarely seen among healthy kids [2-4]. The clinical picture of $\mathrm{HZ}$ in children differs from adults. The duration of the disease is shorter, and complications are seldom observed. Contrary to the findings in adults, pain complaints are rarely seen, and itching is at the forefront $[1,2,4]$. Complications such as postherpetic neuralgia, cranial nerve palsy, myelitis, and stroke can be seen rarely in children [7].

In this article, we aimed to present the $\mathrm{HZ}$ seen in two healthy adolescents, to show that the disease is seen in healthy children, although rare, and to remind and discuss the treatment with adolescent and childhood clinical features. Since HZ cases seen in healthy individuals in the adolescent age group are very few in the literature, it was also aimed to contribute to the literature.

\section{Case Presentation}

\section{Case 1}

An eleven-year-old boy presented to our outpatient clinic five days ago due to the complaint of mild pain and itching on the right side of the chest and back, followed by rashes in the same area. It was learned that he did not use immunosuppressive medications, he did not have an immune failure, had no chickenpox vaccine, and had a chickenpox infection at the age of four. The history revealed that the patient was in the exam period at the school and had a stressful process. On physical examination, there were vesiculopustular lesions on an erythematous floor that did not exceed the midline on the T2-6 dermatomes (Figure 1). There was no fever and lymphadenopathy. Other physical examination findings were normal. In the laboratory examination, hemoglobin was $13.6 \mathrm{~g} / \mathrm{dl}(8-17)$, leukocyte was 5.200/ $\mathrm{mm}^{3}$ (3-15.000), and platelet count was $246.000 / \mathrm{mm}^{3}(150$ 400.000). Alanine aminotransferase (ALT) was determined as $25 \mathrm{U} / \mathrm{L}(0-40)$, aspartate aminotransferase (AST) $32 \mathrm{U} / \mathrm{L}$ (0-41), urea 18 mg/dL (1743), BUN $8.4 \mathrm{mg} / \mathrm{dL}$ (8-20), creatinine $0.27 \mathrm{mg} / \mathrm{dL}$ (0.26-0.77), sodium (Na) $140.7 \mathrm{mmol} / \mathrm{L}$ (136-145), potassium (K) $4.48 \mathrm{mmol} / \mathrm{L}$ (3.5-5), and chlorine $(\mathrm{Cl}) 105.2 \mathrm{mmol} / \mathrm{L}$ (98-110). The results of VZV IgG and M were positive, while HZV IgG and M were negative. Oral acyclovir treatment was started. Lesions regressed within a week, and at the end of the second week, the lesions healed without complications.

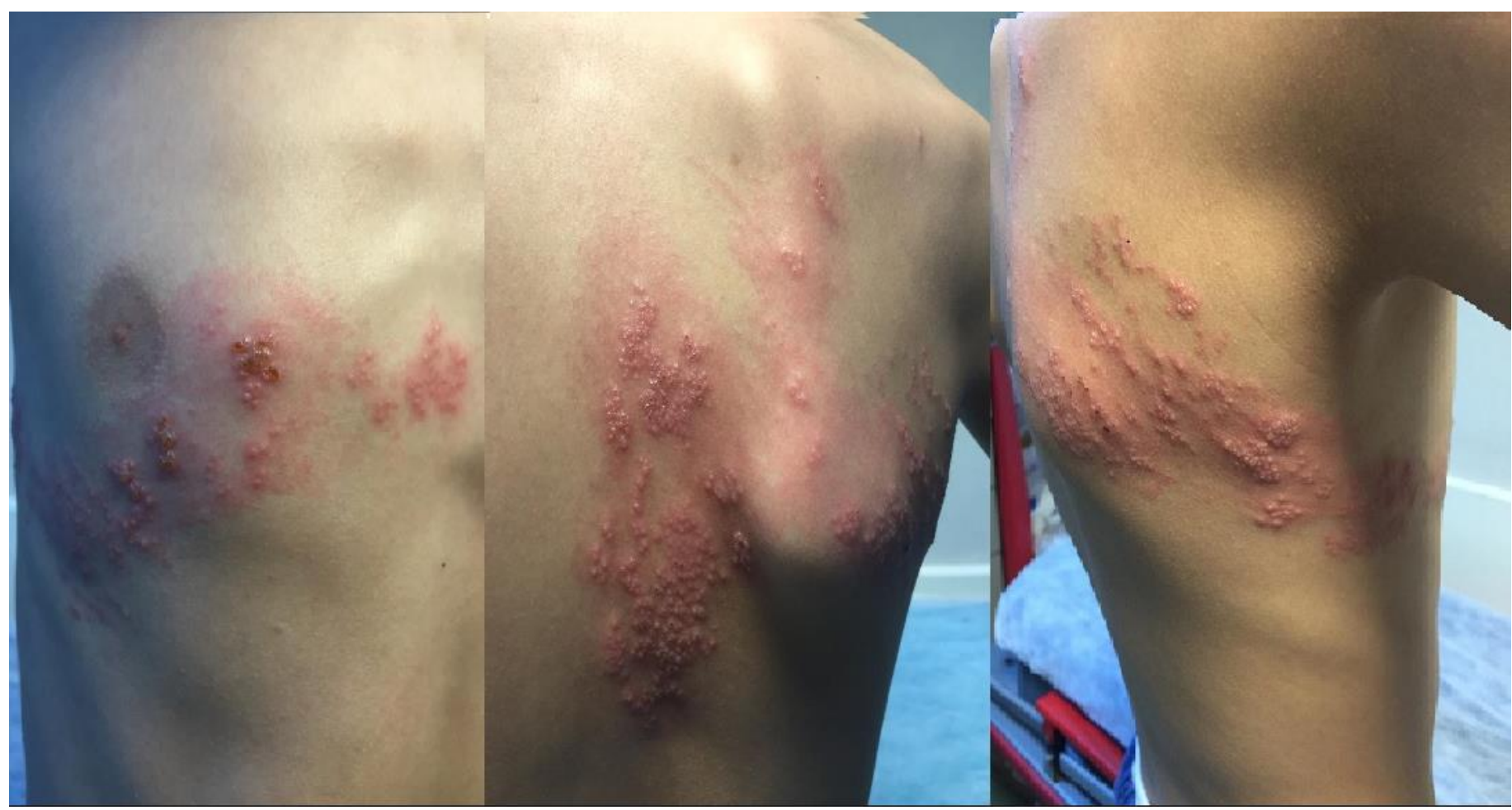

Figure 1. Vesiculopustular lesions on an erythematous ground that does not exceed the midline seen on the T2-6 trace.

\section{Case 2}

A ten-year-old boy applied to our clinic with a three-days-history of itching and mild pain in the right abdomen, followed by rashes in the same area. As to his clinical history, he did not use any immunosuppressive medications, had no immune failure, had no chickenpox vaccine, and had a chickenpox infection at the age of four. Per medical history, the patient had an exam period, was experiencing stressful times, and had a high fever a week ago due to dental abscess. On physical examination, there were vesiculopustular lesions on an erythematous floor that did not exceed the midline of the T9-11 dermatomes (Figure 2). There was no fever and lymphadenopathy. Other physical examination findings were normal. In the laboratory examination, hemoglobin was $12.9 \mathrm{~g} / \mathrm{dl}$ (8-17), leukocyte was 7.800/mm3 (3-15.000), and the platelet count was 350.000/mm3 (150- 
400.000). ALT was determined as $32 \mathrm{U} / \mathrm{L}$ (0-40), AST $35 \mathrm{U} / \mathrm{L}$ (0-41), urea $20 \mathrm{mg} / \mathrm{dL}$ (17-43), BUN $9.5 \mathrm{mg} / \mathrm{dL}$ (8-20), creatinine 0.32 mg/dL (0.26-0.77), Na $138 \mathrm{mmol} / \mathrm{L}$ (136-145), K $4.23 \mathrm{mmol} / \mathrm{L}$ (3.5-5), and Cl $102.7 \mathrm{mmol} / \mathrm{L}$ (98-110). The results of VZV IgG and M were positive, while HZV Ig G and M were negative. Oral acyclovir treatment was initiated. Lesions regressed within a week, and at the end of the second week, they healed without complications.

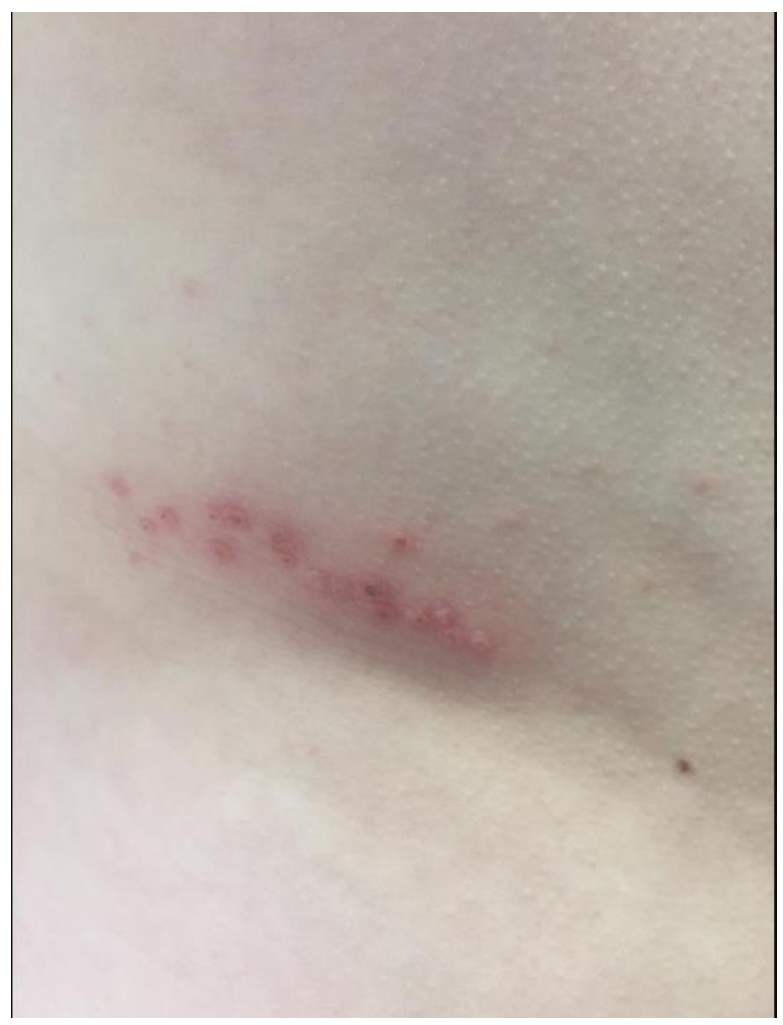

Figure 2. Vesiculopustular lesions on the erythematous ground that do not exceed the midline at the T9-11 dermatomes.

\section{Discussion}

VZV, a member of the herpes virus family, is a double-chain and enveloped DNA virus [5]. Although the mechanism of VZV reactivation, causing herpes zoster to appear, is not fully understood, it is thought to be associated with the suppression of cellular immunity [1]. Whenever cellular immunity is suppressed (especially lymphoproliferative disease, malignancy, human immunodeficiency virus, and immunosuppressive therapy), the condition is more likely to occur at any age [23]. Both of our cases had no known immune suppression or immune deficiency; no pathologies were observed in the peripheral smears, and they were serologically Anti-HIV negative.

The most essential risk factors in healthy children are exposure to intrauterine VZV infection and a history of having chickenpox in the first year of life [1,4]. In this process, infants are protected with antibodies specific to transplacental maternal VZV. However, this is not sufficient for the development of cellular and humoral immunity required for HZ [4]. Both of our patients had a chickenpox infection in childhood. HZ is rarely seen in healthy children. Studies have reported that chronic stress can be a factor in healthy children diagnosed with HZ [5]. Both of our patients were in the exam period and had a stressful process.

The clinical picture of the disease is in the form of vesicles on the erythematous ground in the area that fits a dermatome as in adults, and usually involves the thoracic, lumbar, and trigeminal dermatomes [4]. In a study by Çiftdoğan in Gaziantep with 19 patients in 2012, the most common involvement was detected with $52.9 \%$ in the thoracic dermatomes [6]. Likewise, in a study conducted by Topkarc1 et al. in Istanbul with 14 patients in 2011, the most common involvement was seen in the thoracic dermatomes, too [4]. Similar to the literature, thoracic dermatomes were involved in our cases. In adult patients, pain is often the primary concern in HZ, while the most common symptom in children is itching [1,2,4]. In both of our cases, mild pain and itching were at the forefront.

Infections seen in healthy children are usually short-termed and have favorable outcomes. Postherpetic neuralgia, which is frequently observed in adults, is mostly not found in children [1-2]. In our cases, symptoms regressed in a short time, and no complications were observed.

As a treatment, systemic antiviral therapy is usually required in immunosuppressive children [1-4]. As the disease is light and self-limiting, in healthy children, systemic treatment is not needed $[2,4,5]$. However, some studies recommend treatment in healthy children as it speeds recovery and reduces complications [1-6]. We treated our patients with acyclovir $2 X 500 \mathrm{mg}$ for five days. They recovered in a short time without complications. The most critical way to prevent VZV infection is vaccination [8]. In Turkey, the VZV vaccine was included in the national vaccination program in 2013 [6]. The cases we present are non-vaccinated children.

\section{Conclusion}

As a result, HZ, which is rarely seen in healthy children, is an acute skin infection characterized by the reactivity of VZV, which is characterized by pain, itching, and rash with dermatomal involvement, and usually does not show complications. We wanted to emphasize that $\mathrm{HZ}$ cases, which are likely to be encountered in primary care, improve in a short period in patients with healthy follow-up and treatment. We think that by including the VZV vaccine into the routine vaccination program, patients can be protected from $\mathrm{HZ}$ and related complications.

Patient's consent: Yes.

Conflict of interest: The authors declare that they have no conflict of interest.

\begin{tabular}{|c|r|l|}
\hline \multicolumn{2}{|c|}{ Author Contributions } & Author Initials \\
\hline SCD & Study Conception and Design & RCT, NU, MMNE, OK \\
\hline AD & Acquisition of Data & RCT, NU, MMNE, OK \\
\hline AID & Analysis and Interpretation of Data & RCT, NU, OK, KK \\
\hline DM & Drafting of Manuscript & NU, OK, KK \\
\hline CR & Critical Revision & NU, MMNE, OK, KK \\
\hline
\end{tabular}

Financial support: None 


\section{References}

1. Adisen E, Aksakal AB. Herpes zoster in childhood. Gazi Med J 2007:18(1);36-8. http://medicaljournal.gazi.edu.tr/index.php/GMJ/article/view/200

2. Iyidal AY, Kilic A. Herpes zoster in a healthy 1.5-year-old boy. Dermatoz 2017;8(1):17081o5. https://doi.org/10.15624.dermatoz1708105

3. Ozuguz P, Kacar SD, Polat S, Karaca S, Kundak A. Childhood zona zoster infection: 12 case reports. Abant Med J 2014; 3(3): 253-6. https://doi.org/10.5505/abantmedj.2014.07108

4. Topkarci Z, Erdogan B, Erkum T, Y1lmaz M. Herpes zoster infection in healthy children. Bakirkoy Med J 2012; 8(4):178-81. https://doi.org/10.5350/BTDMJB201208405

5. Balamtekin B, Unay B, Kalman S, Akın R. Herpes zoster in two healthy children. Gulhane Med J 2004;46(2):169-71. http://gulhanemedj.org/archives/archive-detail/article-preview/herpes-zoster-with-two-healthy-children/32753

6. Ciftdogan DY. The time of the primary varicella zoster virus infection in previously healthy children with herpes zoster: is it important? J Pediatr Inf 2017;11(2):71-75. https://doi.org/10.5578/ced.201723

7. Demir M, Aksoy M. Lumbosacral region herpes zoster case in healthy child. Van Med J 2017;24(4):394-6. https://doi.org/10.5505/vtd.2017.97759

8. Colgecen E, Kucuk S, Balci M. Clinical features of herpes zoster infections in childhood. Turk Derm 2012; 46(1): 26-8. https://doi.org/10.4274/turkderm.94899 